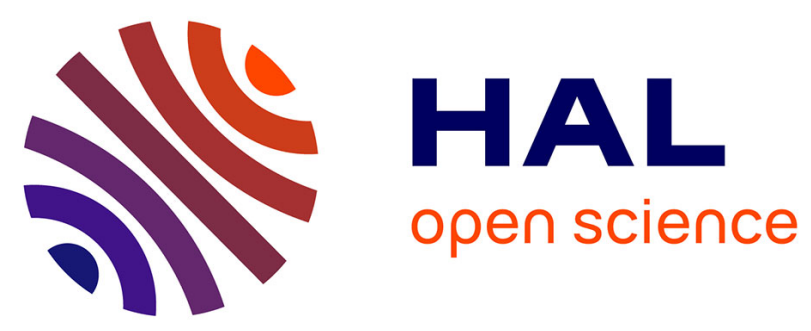

\title{
Mechanisms governing subcompartmentalization of biological membranes
}

Julien Gronnier, Anthony Legrand, Antoine Loquet, Birgit Habenstein, Veronique Germain, Sébastien Mongrand

\section{To cite this version:}

Julien Gronnier, Anthony Legrand, Antoine Loquet, Birgit Habenstein, Veronique Germain, et al.. Mechanisms governing subcompartmentalization of biological membranes. Current Opinion in Plant Biology, 2019, 52, pp.114-123. 10.1016/j.pbi.2019.08.003 . hal-02383351

\section{HAL Id: hal-02383351 \\ https://hal.science/hal-02383351}

Submitted on 27 Nov 2019

HAL is a multi-disciplinary open access archive for the deposit and dissemination of scientific research documents, whether they are published or not. The documents may come from teaching and research institutions in France or abroad, or from public or private research centers.
L'archive ouverte pluridisciplinaire HAL, est destinée au dépôt et à la diffusion de documents scientifiques de niveau recherche, publiés ou non, émanant des établissements d'enseignement et de recherche français ou étrangers, des laboratoires publics ou privés. 
Dear author,

Please note that changes made in the online proofing system will be added to the article before publication but are not reflected in this PDF.

We also ask that this file not be used for submitting corrections. 


\section{ScienceDirect}

\section{i Mechanisms governing subcompartmentalization of biological membranes Sébastien Mongrand ${ }^{1}$}

${ }^{7}$ Q3 Membranes show a tremendous variety of lipids and proteins operating biochemistry, transport and signalling. The dynamics and the organization of membrane constituents are regulated in space and time to execute precise functions. Our

Q4 understanding of the molecular mechanisms that shape and govern membrane subcompartmentalization and interorganelle contact sites still remains limited. Here, we review some reported mechanisms implicated in regulating plant membrane domains including those of plasma membrane, plastids, mitochondria and endoplasmic reticulum. Finally, we discuss several state-of-the-art methods that allow nowadays researchers to decipher the architecture of these structures at the molecular and atomic level.

\begin{abstract}
Addresses
${ }^{1}$ Univ. Bordeaux, CNRS, Laboratoire de Biogenèse Membranaire (LBM), UMR 5200, 33140 Villenave d'Ornon, France

${ }^{2}$ Department of Plant and Microbial Biology, Zurich-Basel Plant Science Center, University of Zürich, Zürich, Switzerland

${ }^{3}$ Institute of Chemistry \& Biology of Membranes \& Nanoobjects (UMR5248 CBMN), IECB, CNRS, Université de Bordeaux, Institut Polytechnique de Bordeaux, All, Geoffroy Saint-Hilaire, Pessac, France
\end{abstract}

Corresponding author:

Mongrand, Sébastien (sebastien.mongrand@u-bordeaux.fr) https://doi.org/10.1016/j.pbi.2019.08.003 1369-5266/৫ 2019 Elsevier Ltd. All rights reserved.

\section{Current Opinion in Plant Biology 2019, 52:xx-yy \\ This review comes from a themed issue on Cell biology \\ Edited by Eva Benkova and Yasin Dagdas}

\section{Introduction}

Spatiotemporal organization of the cellular biomolecules is critical to coordinate the numerous activities simultaneously carried out by cells. Biological membranes delimit cells and organelles and constitute specialized subunits that are constantly reshaped to adapt to everchanging environmental conditions and to operate cell functions effectively (Special issue on cell biology edited by Ref. [1]). Cell membranes are composed of a specific set of biomolecules defining their identity. For example, phosphoinositide lipids and small GTPases proteins are major contributors to endosome identity [2,3]. A tremendous body of evidence shows that the motion and the organization of membrane constituents are dynamically regulated on the level of the membrane to form functional domains and this conversely throughout the tree of life $\left[4^{\bullet \bullet}, 5,6\right]$. Thus, it appears that membrane subcompartmentalization into domains is universal and may represent an essential characteristic. Taking into account the knowledge acquired in various model organisms and model systems over the past decades, membrane domains can be defined as membrane regions in which the local composition, lateral organization, and/or dynamics differ in some way from the average membrane properties [7-9]. Such local specificity is dictated by preferential intermolecular interactions, including intra-membrane interactions (i.e lipid-protein, lipid-lipid and protein-protein) and associations with structures peripheral to the membrane for example cortical cytoskeleton and the cell wall in the case of plasma membrane. This also leads to the formation of inter-membrane interaction through Membrane Contact Sites (MCS), important functional platforms for the exchange of lipids and signalling proteins $[10,11]$, see Figure 1. Yet, membranes being constituted of several thousands of molecules surrounded by variable and complex environments, a tremendous mechanistic complexity remains to be uncovered. Here, we review some described mechanisms regulating membrane architecture in plants and discuss recent technological advancements allowing researchers to study membrane organization with molecular and atomic resolution.

\section{Examples of subcompartmentalization of plant membranes}

\section{Plasma membrane domains}

The plasma membrane (PM) is the outermost boundary of the cell, acting as a communication headquarter integrating signal from the environment to the cell interior and vice-versa. The PM is asymmetric, as exemplified by the enrichment of sphingolipids in the outer leaflet and phospholipids in the inner leaflet $[12,13]$. The PM associates with the cortical cytoskeleton network and the cell wall creating a continuum at the cell surface [14]. PM establishes MCS with organelles, notably with ER at the level of PD, see Figures 1a and 2. The lipid and protein composition of the domains formed at these MCS is very 
2 Cell biology

Figure 1
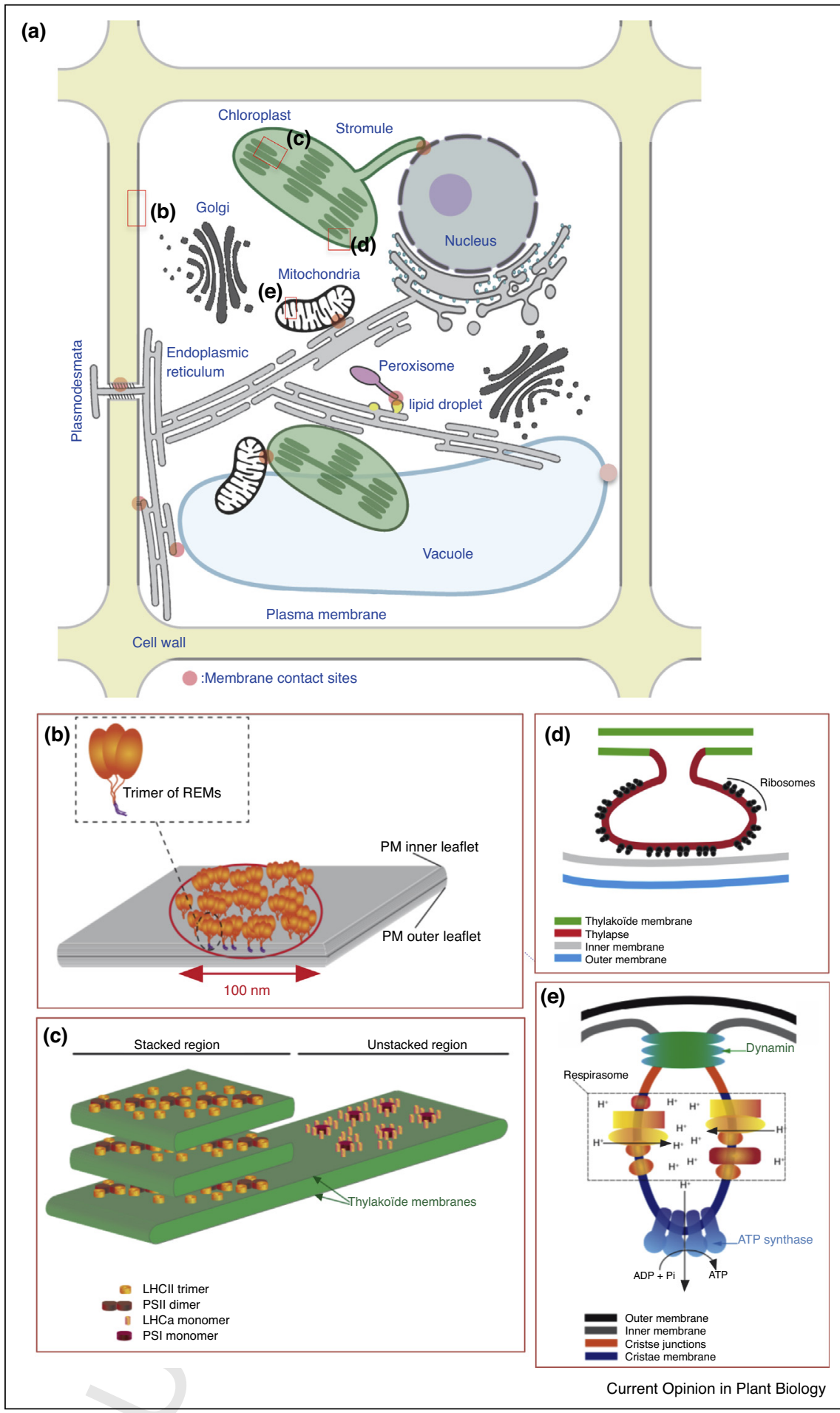

Examples of subcompartmentalization of membranes and membrane contact sites (MCS) in different organelles of plant cells. (a) Scheme of a plant cell showing the membrane contact sites (MCS) between organelles shown by a red dot. Few examples of subcompartmentalization of biological membranes are emphasized in the plasma membrane (b), thylakoids (c), chloroplast envelope (d), mitochondria cristae (e). 


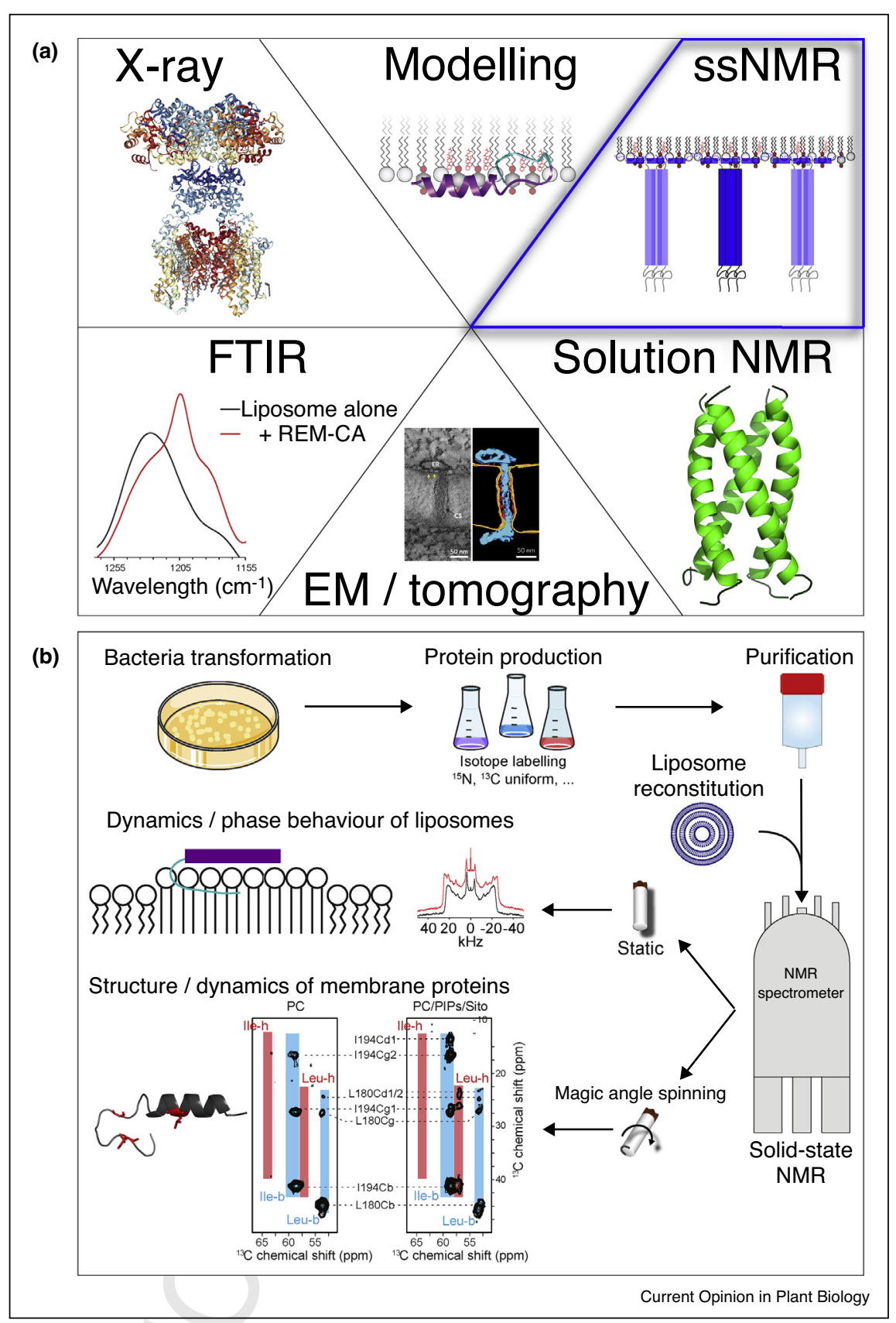

Biophysical techniques to study membrane domains.

(a) Examples of major biophysical tools to analyse membrane domains and membrane-associated proteins, subsequently deciphering the molecular mechanisms at play in nanodomain organization. X-ray: shaker family voltage-dependent potassium channel Kv represented in the cartoon, lipids in stick (PDB: 2R9R, [111]). Modelling: C-terminal anchor of StREM1.3 interacting with membranes enriched in phosphoinositol-4phosphate and sitosterol. ssNMR: model of StREM1.3 nanodomains. FTIR: insertion of C-terminal anchor of StREM1.3 in nanodomain-like membranes [16*0]. EM/tomography: observation of ER-PM membrane contact sites at plasmodesmata [89*0]. Solution NMR: membraneembedded domain of the Influenza B BM2 integral protein (PDB: 2KIX, [112]). (b) ssNMR workflow to study membrane domain-associated proteins. Bacterial expression cells (e.g. E. coli BL21-DE3) are transformed with a high expression level plasmid coding for the protein of interest. Protein production is achieved in minimal culture media supplemented with isotope labelled metabolites depending on the desired isotopic labelling scheme of the protein (e.g. $13 \mathrm{C}$-glucose, $1,3-{ }^{13} \mathrm{C}$-glycerol, $2-{ }^{13} \mathrm{C}$-glycerol . . .). Proteins are purified and reconstituted into liposomes of a chosen lipid composition. ssNMR allows obtaining two types of structural data: magic angle spinning (MAS) ssNMR is used to analyze the structure and dynamics of the membrane protein $\left[16^{\circ}\right]$, and ${ }^{2} \mathrm{H}$ (unpublished typical data) and ${ }^{31} \mathrm{P}$ (not shown) ssNMR to decipher the dynamics and phase behavior of the membranes of interest comprising deuterated lipids. 
specific [11]. Organization of the PM can be rationalized into two types: microdomains and nanodomains. Microdomains are site-specific enrichment of membrane compounds at the cellular level usually referred to as polar domains that control localized cell activities. Nanodomains represent submicrometric heterogeneity of the PM whose visualization often requires the use of high or superresolution microscopy techniques $[15,9]$. Nanodomains have been proposed to act as dedicated platforms regulating cell signalling notably $\left[4^{\bullet \bullet}, 16^{\bullet \bullet}, 9,17^{\bullet}, 15\right]$. Mechanisms regulating the organization of PM domains being recently reviewed $[9,15,13,18-22]$, we present here only three case studies to illustrate the molecular mechanisms at play in the organization and dynamics of PM domains.

REMORINs are plant-specific proteins regulating notably immunity [23-26], symbiosis [27,28,29 $]$ and development [30] possibly by modulating nanodomain-associated complexes $\left[16^{\bullet}, 31,32,17^{\bullet}, 29^{\bullet}\right]$. REMORINs predominantly associate with the PM $[33,23,31,34,35]$. In addition, isoforms from group 1 and group 6 REMORINs have been shown to be associated with plasmodesmata (PD) in Rice and in Solanaceae [23,36,30,31]. Electron microscopy immunolocalization, stimulated emission depletion microscopy (STED) and photoactivated localization microscopy (PALM) studies showed group 1 REMORINs are organized into nanodomains of about $70-90 \mathrm{~nm}$ in diameter that are sensitive to sterol composition $\left[23,37,16^{\bullet \bullet}\right]$ and cytoskeleton integrity [38]. Molecular mechanisms at the basis of REMORIN domain organization are being discovered: REMORINs are targeted from the cytosol to the cytosolic leaflet of the PM via a short unconventional sequence at the extremity of the C-terminus of the protein, called REM-CA (REMORIN C-terminal Anchor) [39,34,40], see Figures 1b and 2; REM-CA undergoes conformational changes upon binding of conserved positively charged residues to phosphoinositides and provides to REMORINs biochemical properties indistinguishable from integral proteins [23,39,16 $\left.{ }^{\bullet}\right]$; REM-CA-sterol-phosphoinositide interactions are required for Group 1 REMORINs supra-molecular organization into functional domains involved in plant response to the Potato Virus X (PVX). Numerous REMORINs present cysteine residues that can be S-acylated [41,34,42,43]. While S-acylation of Arabidopsis REMORINs seems to regulate PM affinity but not primarily nanodomain organization [34], the substitution of an S-acylated cysteine of Nicotiana benthamiana REM alters nanodomain organization [43], suggesting functional divergence of REMORIN S-acylation. Oligomerization of group 1 REMORINs into homotrimers is required for PM localization [39,44], suggesting that REMORINs' self-assembly constitute an early step of PM targeting. Furthermore, REMORIN organization seems regulated by intermolecular protein association. Indeed, in Medicago, FLOT4 scaffolds SYMBIOTIC REM1 to recruit the Nod factor co-receptor LYSINE MOTIF KINASE 3 (LYK3) to specific nanodomains controlling root hair infection by Sinorhizobium meliloti and the establishment of symbiosis $\left[29^{\circ}\right]$. Interaction of AtREM1.3 with AtHIR1 in Arabidopsis suggests that association of SPFH (Stomatin, Prohibitin, Flotillin, HflK/C) proteins with REMORINs may represent a conserved core module shaping PM organization [45]. Finally, phosphorylation of group 1 REMORINs upon infection of $N$. benthamiana by the PVX modulates REM1.3 organization and function [31], probably through the modulation of protein-protein interactions. Thus the genesis and regulation of REMORIN nanodomains appear to rely on several molecular mechanisms such as post-translational modifications, and protein-lipid and protein-protein interactions.

Rho of Plants (ROPs) are the plant-specific subfamily of Rho/Rac small GTP binding proteins, regulating numerous cellular processes such as signalling, trafficking and cytoskeleton dynamics $[46,47]$. Reversible switch from a GDPbound state to a GTP-bound state mediated by ROP-GEFs and ROP-GAPs regulates ROPs activity [48]. Polarization of the growth machinery to a predefined root hair initiation domain (RHID) pledges root hair formation in trichoblast cells. ROP2, 4 and 6, are recruited to the RHID before any detectable cell bulging and serve as a landmark for the recruitment of downstream effectors $\left[49,50^{\circ}\right]$. Strikingly, guanine nucleotide exchange factor 3 (GEF3) defines the RHID by guiding ROPs polarization via direct proteinprotein binding $\left[50^{\circ}\right]$. At the bulging stage, phosphatidylinositol-4-phosphate 5-kinase 3 (PIP5K3), the AGCVIII kinase D6 PROTEIN KINASE (D6PK) and sterol composition modulate ROPs association to the RHID [51,52]. Here, co-regulation of ROP, phosphoinositides and phosphoinositide kinases has been proposed to form a self-organizing system amplifying ROP recruitment and activation [3]. In addition, ROPs associate with the PM via post-translational lipid modifications and direct interaction with membrane lipids mediated by the carboxyterminal tail $\left[53,47,4^{\bullet \bullet}\right]$. For example, ROP6 interacts with phosphatidylserine (PS) via its polybasic tail, a process likely at the basis of nanodomain organization. Recently, using live superresolution microscopy, Platre $e t$ al. elegantly showed that variation in PS level during root development stabilized ROP6 into nanodomains to regulate auxin signaling [ $\left.4^{\bullet \bullet}\right]$. In metaxylem vessel cells, ROP-GEF4 locally activate ROP11 to recruit MICROTUBULE DEPLETION DOMAIN 1 scaffold protein which in turn recruits microtubuledepolymerizing kinesin-13A enabling the formation of pits in secondary cell walls $[54,55]$. IQD13 associates with cortical microtubules (cMTs) and the PM to laterally restrict the localization of ROP GTPase domains, establishing a lateral fence for ROP GTPase [56]. In contrary, CORTICAL MICROTUBULE DISORDERING1-induced disorganization of cortical microtubules impairs the boundaries of PM domains of active ROP11 GTPase [57].

Cellulose microfibers are synthesized by the PMembedded cellulose synthase (CESA) complexes (CSCs) 
which are composed of $18-36$ cellulose synthase subunits [58]. Cortical microtubules recruit CESA-containing vesicles and guide the trajectory of CSCs at the PM [59-61]. In addition, S-acylation of CESAs influences its immediate membrane environment and conditions their location to the PM [62]. CSCs are tethered to cortical microtubules via two integral components, CELLULOSE SYNTHASE INTERACTING 1 [63-65] which determines the trajectory of CSCs along the cMTs [59] and COMPANION OF CELLULOSE SYNTHASE 1 (CC1), which sustains cellulose synthesis by promoting the formation of a stresstolerant microtubule array during salt stress [66].

These examples emphasized that regulation of plasma membrane subcompartmentalization is regulated as part of developmental program, is modulated to respond to environmental clues, relies on the cooperation of multiple factors and is fundamental for function.

\section{Chloroplastic membrane domains}

Chloroplasts are organelles composed of a double membrane envelope and thylakoids found in plant cells and algae that conduct photosynthesis. Little is known about how the photosynthetic membrane machinery is arranged in time and space. Microscopy and biophysical shreds of evidence showed the coexistence of domains where lipids are organized in lamellar or hexagonal phases. For example, hexagonal phases have been described in etioplasts of prolamellar bodies or during the transfer of lipids between the envelope and thylakoids, such hexagonal phase domains may be of importance for localizing metabolic activities, for example the violaxanthine-epoxidase in thylakoid domains [67].

Biochemical, 3D reconstruction, in vivo spectroscopy and immunolocalization data, reveal that thylakoids display a heterogeneous subcompartmentalization of photosynthetic complexes in domains which redistribute during state transitions in Chlamydomonas [68] and diatoms [69], see Figure 1c. These domains are interconnected, ensuring fast equilibration of electron carriers for efficient and optimal photosynthesis. Underlying molecular events at the basis of thylakoid subcompartmentalization remain unclear. Thylakoids possess a special fatty acid namely trans- $\Delta 3$-hexadecenoic acid (trans-16:1) esterified in phosphatidylglycerol (PG) which may play a role in cementing thylakoids during granum formation and control of light reactions of photosynthesis [70]. Recent 3D cryo-electron tomography showed the thylakoid network of cyanobacteria is organized in domains and forms a synapse-like MCS decorated by ribosomes (but not by phycobilisomes) in tight association with the PM of cyanobacteria. This MCS was named the 'thylapse', for 'thyl(akoid syn)apse', and likely serves for compartmentalization of the different functions of the thylakoids that is photosynthesis or protein synthesis $\left[71^{\bullet \bullet}\right]$, see Figure 1d. Because PM of cyanobacteria represents the inner membrane of eukaryotic plastids, thylapses most likely also exist in higher plants.

Chloroplast envelope establishes numerous MCS with other organelles [10]. For example, plastid and mitochondrion envelopes establish membrane connection during phosphate deprivation. The molecular content of this MCS has been recently identified by biochemical and proteomic approaches and showed a big complex of hundred proteins enriched in specific lipids. AtMic60, a conserved protein of the mitochondria inner membrane, plays a crucial role in the lipid transport process by regulating the proximity between mitochondrial membranes via its interaction with the outer membrane protein Tom 40 and by destabilizing membranes, likely to promote lipid desorption $\left[72^{\circ \bullet}\right]$. Plastids can also undergo drastic changes in shape under stress, through specialized protrusive membrane domains called stromules (stroma-filled tubules, see Figure 1a) which link plastid envelope with other organelles such as ER, Golgi and nucleus [73,74]. The molecular mechanisms governing stromule formation are not established, but the involvement of cytoskeleton motors has been proposed [75]. Similarly, peroxules, peroxisomal protrusions tethering chloroplasts or mitochondria through specialized membrane microdomains have been evidenced [76,77]. Peroxules also for example link with lipid droplets, see section 'Endoplasmic reticulum domains'. These studies reveal the importance of physical connections through plant membrane domains for establishing complex metabolic pathways.

\section{Mitochondrial membrane domains}

Mitochondria are double-membrane-bound organelles. The outer mitochondrial membrane encloses the entire organelle and can be in contact with other organelles for example during phosphate starvation, see above [10]. The inner membrane separates the mitochondrial matrix from the intermembrane space. The structure of the inner mitochondrial membrane is extensively folded. These invaginations are separated from the inner membrane by dynamin proteins to form three domains namely, the inner boundary membrane, the cristae junctions and the cristae membranes [78], see Figure 1e. The latter contains enzymes of the mitochondrial respiratory chain that, instead of being dispersed in the membrane, are organized into a functional supramolecular respiratory domain called respirasome, see Figure 1. ATP synthase dimers sit at the edge of the cristae. Mitochondria inner membrane is rich in cardiolipin (CL), a key phospholipid playing important roles in maintaining the functional integrity and dynamics of mitochondria. Arabidopsis CL localizes to mitochondria and is enriched at specific domains and CARDIOLIPIN SYNTHASE targets to the inner membrane of mitochondria with its C-terminus in the intermembrane space [79]. Mitochondria of $\mathrm{cls}$ mutants exhibit altered structural integrity and morphogenesis. In contrast to animal and yeast, plant CL plays a dominant role in mitochondrial fission and exerts this 
function through stabilizing the protein complex of DYNAMIN-RELATED PROTEIN3 [79]. In addition, CL induces membrane invaginations which are stabilized by dimers of ATP synthase. In reconstituted systems, bovine ATP synthase is sufficient to deform a lipid bilayer, which is likely the driving force triggering cristae curvature [80]. Recently, dimers of mitochondrial ATP synthase from the green algae Polytomella were shown to be required for cristae formation and constitute the main factor in mitochondrial morphogenesis to induce membrane curvature and self-assembly into rows [ $\left.81^{\circ}\right]$. Finally, mitochondria-associated ER membrane (MAM) is another structural element that is increasingly recognized for its critical role in cellular physiology and homeostasis of mitochondria [10].

\section{Endoplasmic reticulum domains}

The endoplasmic reticulum forms a membrane network virtually in contact with all cell organelles, see Figure 1a. Thus, the ER is actively engaged in organizing membrane domains to perform various functions. For example, ER is known to be organized into smooth and rough domains, the latter being enriched in ribosomes involved in protein production, protein folding, quality control and dispatch. Formation of these domains is regulated by syntaxin proteins [82]. Lipid droplets (LD) are lipid-rich cellular organelles regulating storage and hydrolysis of neutral lipids. LD biogenesis takes place at ER subdomains which are regulated by lipodystrophy proteins called SEIPINs in human, yeast, and plants. SEIPINs reorganize the normal, reticulated ER structure into discrete ER domains that colocalize with LD. In plants, SEIPINs modulate the number and sizes of $\operatorname{LD}\left[83^{\circ}, 84\right]$. Recent work in plants showed that peroxisome extensions deliver the major TAG lipase Sugar-Dependent 1 (SDP1) to the LD. At early stages of seedling development, SDP1 localizes to a peroxisome membrane domain and then possibly moves to the LD surface through peroxisome tubulations [85]. This constitutes an interesting case of inter-organelle communication and protein transport that is reminiscent of stromule.

In the next chapter, we will briefly describe state-of-the-art biophysical methods that have provided access to the structural basis membrane domain organization.

\section{How to study the molecular mechanisms shaping biological membrane domains in plants?}

Membrane subcompartmentalization is intimately linked to the preferential association of membrane constituents. Therefore, establishing the structure-function relationship between the membrane subcompartment components is an essential piece of the puzzle towards understanding the complex interplay of the cells with the extracellular environment. Yet, the intrinsic soft matter state of membranerelated systems in their native environment, such as peripheral or membrane-embedded proteins, hampers the application of numerous techniques in structural biology to visualize molecular association at the atomic level. To provide an overview on a promising route towards understanding the molecular basis underlying membrane subcompartmentalization, we can list tools such as X-ray, crystallography and solution NMR [86-88]. The recent developments of superresolution microscopy (eg. STED, PALM), cryo-electron microscopy (EM) and tomography methods allowed the study of the organization of proteins and lipids and the characterization of membrane subcompartmentalization and MCS $\left[89^{\bullet \bullet}, 16^{\bullet \bullet}, 90^{\bullet}\right]$ with unpreceded resolution. The complementary biophysical tools to investigate lipid/protein interactions such as Langmuir monolayer, Fourier-Transform InfraRed spectroscopy (FTIR), NMR or modelling are reviewed in $[91,11,13]$. Figure 2a shows several examples of diverse contributions, including solid-state nuclear magnetic resonance (ssNMR), X-ray crystallography, modelling, FTIR, tomography by EM and solution NMR. The development of lipid and protein imagery by isotope-labeled high-resolution secondary ion mass spectrometry (nano-SIMS) would allow the study of molecular events at play in domain formation and dynamics [92,93]. In plants, nano-SIMS was used to localize elements such as manganese, arsenic, iron, zinc, and cadmium at the nanoscale level [94], but this approach could also be used for lipids and proteins in internal organelles.

Here, we further describe the powerful technique ssNMR that emerges as a tool to understand domain assembly. SsNMR is a versatile technology reporting on membrane and protein structure, sensitive to dynamics and proteinlipid interactions. A major advantage relies in its application on systems in the native bilayer environment, that is reconstituted liposomes that can represent membranes of a chosen lipid composition. The flowchart in Figure $2 \mathrm{~b}$ illustrates the overall procedure applied to inquire on the previously mentioned aspects of membrane-associated proteins. Reporting membrane biophysical and structural parameters are achieved by well-established membrane-focused ssNMR, mainly recorded on ${ }^{2} \mathrm{H}$ and ${ }^{31} \mathrm{P}$ nuclei $[95,96]$. The quadrupolar ${ }^{2} \mathrm{H}$ signal in static ssNMR encodes for the overall lipid mobility and, importantly, the local dynamics along the acyl chain. Upon varying the membrane components (lipid composition, presence or absence of protein) and environment (temperature, $\mathrm{pH}$ ), ${ }^{2} \mathrm{H}$ ssNMR reveals detailed insights on phase, phase transitions, acyl chain dynamics and membrane thickness and curvature depending on the precise lipid composition and on the presence of a potential interaction partner. The chemical shift of ${ }^{31} \mathrm{P}$ nuclei complements and corroborates the data reporting on phase behavior and the impact of potential partner molecules on the lipid head groups. Tackling membrane proteins is based on Magic-Angle spinning (MAS) ssNMR, a method which has seen tremendous advances in elucidating insoluble protein structures, dynamics and interactions in soft matter states such as assemblies, aggregates $\left[97^{\bullet}, 98,99\right]$ or 
membrane-association $\left[100^{\bullet \bullet}, 101,102\right]$. Since 2002, when the first structure of a microcrystalline protein has been solved by MAS ssNMR [103], the technology has proven very powerful to elucidate protein assemblies such as the first amyloid protein structure [104], bacterial filaments $[105,106]$ and protein-membrane complexes $\left[107^{\circ}\right]$. A considerable knowledge has already been derived from ssNMR on protein-lipid, lipid-lipid interactions and membrane dynamics and functioning [108-110,96,102]. Most recent technological developments achieving ultra-fast MAS frequencies $(\geq 100 \mathrm{kHz})$ MAS ssNMR allow for observing proton nuclei in protonated protein samples $(\sim 500 \mu \mathrm{g})$ and should facilitate ssNMR to serve as a common tool for structural biology on membrane/ protein related questions. Because of its striking technological evolution, MAS ssNMR has recently been applied in few cases to shed light on protein structures, dynamics and protein-lipid interactions promoted by lipid-dependent membrane features [100 ${ }^{\bullet \bullet}$ ]. Membrane domain formation in plants, relying on the plant protein and lipid interplay (see below the example of REMORIN in PM $\left[16^{\bullet \bullet}, 44\right]$ ) remains a field to explore by MAS ssNMR.

\section{Conclusions}

Virtually all membranes are organized in functional domains that coordinate cell functions. Recent breakthrough in biochemistry, biophysic and microscopy approaches allow nowadays the study of the mechanisms regulating the formation of membrane domains, particularly the interplay between lipids and proteins. The next decade will likely open a vast area of research to understand the roles of membrane organization during plant development and adaptation.

\section{Conflict of interest statement}

$$
\text { Nothing declared. }
$$

\section{Acknowledgements}

This work was sustained by CNRS (Centre National de la Recherche Scientifique) and the University of Bordeaux. We thank the European Molecular Biology Organization (EMBO Long-Term Fellowship 438-2018) for financial support to J.G. This work has benefited from the facilities of the Bordeaux Metabolome/lipidome Facility-MetaboHUB to SM, VG (grant no. ANR-11-INBS-0010), a CNRS Momentum project to BH, and an ERC Starting Grantproject "WEAKINTERACT" to AL. We thank Christophe Rocher (LBM, Bordeaux) and Juliette Jouhet (LPCV, Grenoble) for fruitful discussions.

\section{References and recommended reading}

Papers of particular interest, published within the period of review, have been highlighted as:

- of special interest

$\bullet$ of outstanding interest

1. Russinova E, Schumacher K: Editorial overview: cell biology: membrane dynamics - being at the right place at the right time. Curr Opin Plant Biol 2017, 40:iii-iv.

2. Jean S, Kiger AA: Coordination between RAB GTPase and phosphoinositide regulation and functions. Nat Rev Mol Cell Biol 2012, 13:463-470.
3. Noack LC, Jaillais Y: Precision targeting by phosphoinositides: how PIs direct endomembrane trafficking in plants. Curr Opin Plant Biol 2017, 40:22-33.

4. Platre MP, Bayle V, Armengot L, Bareille J, Marques-Bueno MDM,

- Creff A, Maneta-Peyret L, Fiche JB, Nollmann M, Miege C et al.: Developmental control of plant Rho GTPase nanoorganization by the lipid phosphatidylserine. Science 2019 , 364:57-62.

In this study, the authors elegantly showed that variation in phosphatidylserine during root development stabilized Rho protein ROP6 into nanodomains to regulate auxin signaling.

5. Garcia-Fernandez E, Koch G, Wagner RM, Fekete A, Stengel ST, Schneider J, Mielich-Suss B, Geibel S, Markert SM, Stigloher C et al.: Membrane microdomain disassembly inhibits MRSA antibiotic resistance. Cell 2017, 171:1354-1367 e1320.

6. Zhou Y, Prakash P, Liang H, Cho KJ, Gorfe AA, Hancock JF: Lipidsorting specificity encoded in K-ras membrane anchor regulates signal output. Cell 2017, 168:239-251 e216.

7. Jacobson K, Liu P, Lagerholm BC: The lateral organization and mobility of plasma membrane components. Cell 2019, 177:806-819.

8. Sezgin E, Levental I, Mayor S, Eggeling C: The mystery of membrane organization: composition, regulation and roles of lipid rafts. Nat Rev Mol Cell Biol 2017, 18:361-374.

9. Gronnier J, Gerbeau-Pissot P, Germain V, Mongrand S, SimonPlas F: Divide and rule: plant plasma membrane organization Trends Plant Sci 2018, 23:899-917.

10. Michaud $\mathrm{M}$, Jouhet $\mathrm{J}$ : Lipid trafficking at membrane contact sites during plant development and stress response. Front Plant Sci 2019, 10:2.

11. Petit JD, Immel F, Lins L, Bayer EM: Lipids or proteins: who is leading the dance at membrane contact sites? Front Plant Sci 2019, 10:198.

12. Cacas JL, Bure $C$, Grosjean $K$, Gerbeau-Pissot $P$, Lherminier J, Rombouts Y, Maes E, Bossard C, Gronnier J, Furt F et al.: Revisiting plant plasma membrane lipids in tobacco: a focus on sphingolipids. Plant Physiol 2015, 170:367-384.

13. Mamode Cassim A, Gouguet P, Gronnier J, Laurent N, Germain V, Grison M, Boutte Y, Gerbeau-Pissot P, Simon-Plas F, Mongrand S: Plant lipids: key players of plasma membrane organization and function. Prog Lipid Res 2019, 73:1-27.

14. McKenna JF, Tolmie AF, Runions J: Across the great divide: the plant cell surface continuum. Curr Opin Plant Biol 2014, 22:132-140.

15. Ott T: Membrane nanodomains and microdomains in plantmicrobe interactions. Curr Opin Plant Biol 2017, 40:82-88.

16. Gronnier J, Crowet JM, Habenstein B, Nasir MN, Bayle V, Hosy E,

-. Platre MP, Gouguet P, Raffaele S, Martinez D et al.: Structural basis for plant plasma membrane protein dynamics and organization into functional nanodomains. eLife $2017,6$.

Combining super resolution microscopy, modelling and biophysical experiements, the authors decipher a molecular mechanism regulating the formation of functional nanodomains invoveld in plant immunity against a virus.

17. Bucherl CA Jarsch IK, Schudoma C, Segonzac C, Mbengue M, - Robatzek S, MacLean D, Ott T, Zipfel C: Plant immune and growth receptors share common signalling components but localise to distinct plasma membrane nanodomains. elife 2017,6

Using quantitative image analysis the authors propose that spatial separation support functional specification of immune and growth receptors kinase.

18. Faulkner C: A cellular backline: specialization of host membranes for defence. J Exp Bot 2015, 66:1565-1571.

19. Burkart RC, Stahl Y: Dynamic complexity: plant receptor complexes at the plasma membrane. Curr Opin Plant Biol 2017, 40:15-21.

20. Tilsner J, Nicolas W, Rosado A, Bayer EM: Staying tight: plasmodesmal membrane contact sites and the control of cell-to-cell connectivity in plants. Annu Rev Plant Biol 2016 67:337-364. 
21. Naramoto S: Polar transport in plants mediated by membrane transporters: focus on mechanisms of polar auxin transport. Curr Opin Plant Biol 2017, 40:8-14.

22. Nakamura $M$, Grebe $M$ : Outer, inner and planar polarity in the Arabidopsis root. Curr Opin Plant Biol 2018, 41:46-53.

23. Raffaele S, Bayer E, Lafarge D, Cluzet S, German Retana S, Boubekeur T, Leborgne-Castel N, Carde JP, Lherminier J, Noirot E et al: Remorin, a solanaceae protein resident in membrane rafts and plasmodesmata, impairs potato virus $X$ movement. Plant Cell 2009, 21:1541-1555.

24. Bozkurt TO, Richardson A, Dagdas YF, Mongrand S, Kamoun S, Raffaele S: The plant membrane-associated REMORIN1.3 accumulates in discrete perihaustorial domains and enhances susceptibility to phytophthora infestans. Plant Physiol 2014 165:1005-1018.

25. Son S, Oh CJ, An CS: Arabidopsis thaliana remorins interact with SnRK1 and Play a role in susceptibility to beet curly top virus and beet severe curly top virus. Plant Pathol J 2014 , 30:269-278.

26. Jamann TM, Luo X, Morales L, Kolkman JM, Chung CL, Nelson RJ: A remorin gene is implicated in quantitative disease resistance in maize. Theor Appl Genet 2016, 129:591-602.

27. Lefebvre B, Timmers T, Mbengue M, Moreau S, Herve C, Toth $\mathrm{K}$, Bittencourt-Silvestre J, Klaus D, Deslandes L, Godiard L et al.: A remorin protein interacts with symbiotic receptors and regulates bacterial infection. Proc Natl Acad Sci U S A 2010, 107:2343-2348.

28. Toth K, Stratil TF, Madsen EB, Ye J, Popp C, Antolin-Llovera M, Grossmann C, Jensen ON, Schussler A, Parniske M et al:: Functional domain analysis of the Remorin protein LjSYMREM1 in Lotus japonicas. PLoS One 2012, 7:e30817.

29. Liang P, Stratil TF, Popp C, Marin M, Folgmann J, Mysore KS,

- Wen J, Ott T: Symbiotic root infections in Medicago truncatula require remorin-mediated receptor stabilization in membrane nanodomains. Proc Natl Acad Sci U S A 2018, 115:5289-5294.

The authors proposed that immobilization of symbiotic cell entry receptor LYK3 is mediated by two molecular scaffold proteins, FLOT4 and SYMREM1 and ensures progression of the primary infection thread into root cortical cells.

30. Gui J, Liu C, Shen J, Li L: Grain setting defect1, encoding a remorin protein, affects the grain setting in rice through regulating plasmodesmatal conductance. Plant Physiol 2014, 166:1463-1478.

31. Perraki A, Gronnier J, Gouguet $P$, Boudsocq M, Deroubaix AF, Simon V, German-Retana S, Legrand A, Habenstein B, Zipfel C et al.: REM1.3's phospho-status defines its plasma membrane nanodomain organization and activity in restricting PVX cellto-cell movement. PLoS Pathog 2018, 14:e1007378.

32. Jarsch IK, Ott T: Perspectives on remorin proteins, membrane rafts, and their role during plant-microbe interactions. $\mathrm{Mol}$ Plant Microbe Interact 2011, 24:7-12.

33. Jarsch IK, Konrad SS, Stratil TF, Urbanus SL, Szymanski W, Braun $\mathrm{P}$, Braun $\mathrm{KH}$, Ott T: Plasma membranes are subcompartmentalized into a plethora of coexisting and diverse microdomains in arabidopsis and Nicotiana benthamiana. Plant Cell 2014, 26:1698-1711.

34. Konrad SS, Popp C, Stratil TF, Jarsch IK, Thallmair V, Folgmann J, Marin M, Ott T: S-acylation anchors remorin proteins to the plasma membrane but does not primarily determine their localization in membrane microdomains. New Phytol 2014, 203:758-769.

35. Marin $\mathrm{M}$, Thallmair $\mathrm{V}, \mathrm{Ott} \mathrm{T}$ : The intrinsically disordered $\mathbf{N}$-terminal region of AtREM1.3 remorin protein mediates protein-protein interactions. J Biol Chem 2012, 287:39982-39991.

36. Fernandez-Calvino L, Faulkner C, Walshaw J, Saalbach G, Bayer E, Benitez-Alfonso Y, Maule A: Arabidopsis plasmodesmal proteome. PLOS One 2011, 6:e18880.

37. Demir F, Horntrich C, Blachutzik JO, Scherzer S, Reinders $Y$, Kierszniowska S, Schulze WX, Harms GS, Hedrich R, Geiger D et al.: Arabidopsis nanodomain-delimited ABA signaling pathway regulates the anion channel SLAH3. Proc Natl Acad Sci U S A 2013, 110:8296-8301.

38. Szymanski WG, Zauber H, Erban A, Gorka M, Wu XN Schulze WX: Cytoskeletal components define protein location to membrane microdomains. Mol Cell Proteomics 2015, 14:2493-2509.

39. Perraki A, Cacas JL, Crowet JM, Lins L, Castroviejo M, GermanRetana S, Mongrand S, Raffaele S: Plasma membrane localization of Solanum tuberosum remorin from group 1, homolog 3 is mediated by conformational changes in a nove C-terminal anchor and required for the restriction of potato virus X movement. Plant Physiol 2012, 160:624-637.

40. Raffaele S, Perraki A, Mongrand S: The remorin C-terminal anchor was shaped by convergent evolution among membrane binding domains. Plant Signal Behav 2013, 8:e23207.

41. Hemsley PA: Assaying protein S-acylation in plants. Methods Mol Biol 2013, 1043:141-146.

42. Gui J, Zheng S, Shen J, Li L: Grain setting defect1 (GSD1) function in rice depends on S-acylation and interacts with actin 1 (OsACT1) at its C-terminal. Front Plant Sci 2015, 6:804

43. Fu S, Xu Y, Li C, Li Y, Wu J, Zhou X: Rice stripe virus interferes with $S$-acylation of remorin and induces its autophagic degradation to facilitate virus infection. Mol Plant 2018, 11:269-287.

44. Martinez D, Legrand A, Gronnier J, Decossas M, Gouguet P Lambert O, Berbon M, Verron L, Grelard A, Germain V et al.: Coiled-coil oligomerization controls localization of the plasma membrane REMORINs. J Struct Biol 2018.

45. Lv X, Jing $Y$, Xiao J, Zhang $Y$, Zhu Y, Julian R, Lin J: Membrane microdomains and the cytoskeleton constrain AtHIR1 dynamics and facilitate the formation of an AtHIR1-associated immune complex. Plant J 2017, 90:3-16.

46. Christensen TM, Vejlupkova Z, Sharma YK, Arthur KM, Spatafora JW, Albright CA, Meeley RB, Duvick JP, Quatrano RS Fowler JE: Conserved subgroups and developmental regulation in the monocot rop gene family. Plant Physiol 2003 133:1791-1808.

47. Feiguelman G, Fu Y, Yalovsky S: ROP GTPases structurefunction and signaling pathways. Plant Physiol 2018, 176:57-79.

48. Berken A, Wittinghofer A: Structure and function of rho-type molecular switches in plants. Plant Physiol Biochem 2008, 46:380-393.

49. Molendijk AJ, Bischoff F, Rajendrakumar CS, Friml J, Braun M, Gilroy S, Palme K: Arabidopsis thaliana Rop GTPases are localized to tips of root hairs and control polar growth. EMBO J 2001, 20:2779-2788.

50. Denninger P, Reichelt A, Schmidt VAF, Mehlhorn DG, Asseck LY,

- Stanley CE, Keinath NF, Evers JF, Grefen C, Grossmann G: Distinct RopGEFs successively drive polarization and outgrowth of root hairs. Curr Biol 2019.

Using microfluidics and live cell imaging, Denninger et al. dissect the timing of the growth machinery assembly in polarizing hair cells and show that GEF3 serves as a membrane landmark recruting growth machinery to specialized membrane domains.

51. Stanislas T, Huser A, Barbosa IC, Kiefer CS, Brackmann K, Pietra S, Gustavsson A, Zourelidou M, Schwechheimer C, Grebe M: Arabidopsis D6PK is a lipid domain-dependent mediator of root epidermal planar polarity. Nat Plants 2015, 1:15162.

52. Barbosa IC, Zourelidou M, Willige BC, Weller B, Schwechheimer C: D6 PROTEIN KINASE activates auxin transport-dependent growth and PIN-FORMED phosphorylation at the plasma membrane. Dev Cell 2014, 29:674-685.

53. Bloch D, Yalovsky S: Cell polarity signaling. Curr Opin Plant Biol 2013, 16:734-742.

54. Oda $\mathrm{Y}$, Fukuda $\mathrm{H}$ : Initiation of cell wall pattern by a Rho- and microtubule-driven symmetry breaking. Science 2012 , 337:1333-1336. 
55. Oda $\mathrm{Y}$, Fukuda $\mathrm{H}$ : Rho of plant GTPase signaling regulates the behavior of Arabidopsis kinesin-13A to establish secondary cell wall patterns. Plant Cell 2013, 25:4439-4450.

56. Sugiyama Y, Wakazaki M, Toyooka K, Fukuda H, Oda Y: A novel plasma membrane-anchored protein regulates xylem cell-wall deposition through microtubule-dependent lateral inhibition of rho GTPase domains. Curr Biol 2017, 27:2522-2528 e2524.

57. Sasaki T, Fukuda $\mathrm{H}$, Oda $\mathrm{Y}$ : Cortical microtubule disordering1 is required for secondary cell wall patterning in xylem vessels. Plant Cell 2017, 29:3123-3139.

58. McFarlane HE, Doring A, Persson S: The cell biology of cellulose synthesis. Annu Rev Plant Biol 2014, 65:69-94.

59. Paredez AR, Somerville CR, Ehrhardt DW: Visualization of cellulose synthase demonstrates functional association with microtubules. Science 2006, 312:1491-1495.

60. Crowell EF, Bischoff V, Desprez T, Rolland A, Stierhof YD, Schumacher K, Gonneau M, Hofte H, Vernhettes S: Pausing of Golgi bodies on microtubules regulates secretion of cellulose synthase complexes in Arabidopsis. Plant Cell 2009, 21:1141-1154.

61. Gutierrez R, Lindeboom JJ, Paredez AR, Emons AM, Ehrhardt DW: Arabidopsis cortical microtubules position cellulose synthase delivery to the plasma membrane and interact with cellulose synthase trafficking compartments.

62. Kumar M, Wightman R, Atanassov I, Gupta A, Hurst $\mathrm{CH}$, Hemsley PA, Turner S: S-acylation of the cellulose synthase complex is essential for its plasma membrane localization. Science 2016, 353:166-169.

63. Bringmann M, Landrein B, Schudoma C, Hamant O, Hauser MT, Persson S: Cracking the elusive alignment hypothesis: the microtubule-cellulose synthase nexus unraveled. Trends Plant Sci 2012, 17:666-674.

64. Gu Y, Somerville C: Cellulose synthase interacting protein: a new factor in cellulose synthesis. Plant Signal Behav 2010, 5:1571-1574.

65. Li S, Lei L, Somerville CR, Gu Y: Cellulose synthase interactive protein 1 (CSI1) links microtubules and cellulose synthase complexes. Proc Natl Acad Sci U S A 2012, 109:185-190.

66. Endler A, Kesten C, Schneider R, Zhang Y, Ivakov A, Froehlich A, Funke N, Persson S: A mechanism for sustained cellulose synthesis during salt stress. Cell 2015, 162:1353-1364.

67. Jouhet J: Importance of the hexagonal lipid phase in biological membrane organization. Front Plant Sci 2013, 4:494.

68. Nawrocki WJ, Santabarbara S, Mosebach L, Wollman FA, Rappaport F: State transitions redistribute rather than dissipate energy between the two photosystems in chlamydomonas. Nat Plants 2016, 2:16031.

69. Flori S, Jouneau PH, Bailleul B, Gallet B, Estrozi LF, Moriscot C, Bastien O, Eicke S, Schober A, Bartulos CR et al.: Plastid thylakoid architecture optimizes photosynthesis in diatoms. Nat Commun 2017, 8:15885.

70. Furse S: Is phosphatidylglycerol essential for terrestrial life? J Chem Biol 2017, 10:1-9.

71. Rast A, Schaffer M, Albert S, Wan W, Pfeffer S, Beck F, Plitzko JM

$\bullet \quad$ Nickelsen J, Engel BD: Biogenic regions of cyanobacterial thylakoids form contact sites with the plasma membrane. Nat Plants 2019, 5:436-446.

Cryo-electron tomography was used here to show that thylakoids organized in domains enriched in ribosomes, but deprived in photosynthetic machinery, to allow contact sites with the cyanobacterial plasma membrane.

72. Michaud M, Gros V, Tardif M, Brugiere S, Ferro M, Prinz WA, -• Toulmay A, Mathur J, Wozny M, Falconet D et al.: AtMic60 is involved in plant mitochondria lipid trafficking and is part of a large complex. Curr Biol 2016, 26:627-639

Elegant biochemical characterization of the MCS between mitochondria and chloroplasts involved in the exchange of DGDG during phosphate deprivation. Nat Cell Biol 2009, 11:797-806.
73. Park E, Caplan JL, Dinesh-Kumar SP: Dynamic coordination of plastid morphological change by cytoskeleton for chloroplast-nucleus communication during plant immune responses. Plant Signal Behav 2018, 13:e1500064.

74. Erickson JL, Kantek M, Schattat MH: Plastid-nucleus distance alters the behavior of stromules. Front Plant Sci 2017, 8:1135.

75. Erickson JL, Schattat MH: Shaping plastid stromules-principles of in vitro membrane tubulation applied in planta. Curr Opin Plant Biol 2018, 46:48-54.

76. Gao H, Metz J, Teanby NA, Ward AD, Botchway SW, Coles B, Pollard MR, Sparkes I: In vivo quantification of peroxisome tethering to chloroplasts in tobacco epidermal cells using optical tweezers. Plant Physiol 2016, 170:263-272.

77. Jaipargas EA, Mathur N, Bou Daher F, Wasteneys GO, Mathur J: High light intensity leads to increased peroxule-mitochondria interactions in plants. Front Cell Dev Biol 2016, 4:6.

78. Quintana-Cabrera R, Mehrotra A, Rigoni G, Soriano ME: Who and how in the regulation of mitochondrial cristae shape and function. Biochem Biophys Res Commun 2018, 500:94-101.

79. Pan R, Jones AD, Hu J: Cardiolipin-mediated mitochondrial dynamics and stress response in Arabidopsis. Plant Cell 2014 26:391-409.

80. Jiko C, Davies KM, Shinzawa-Itoh K, Tani K, Maeda S, Mills DJ, Tsukihara T, Fujiyoshi Y, Kuhlbrandt W, Gerle C: Bovine F1Fo ATP synthase monomers bend the lipid bilayer in 2D membrane crystals. eLife 2015, 4:e06119.

81. Blum TB, Hahn A, Meier T, Davies KM, Kuhlbrandt W: Dimers of mitochondrial ATP synthase induce membrane curvature and self-assemble into rows. Proc Natl Acad Sci U S A 2019.

Use of electron cryotomography provided experimental proof that mitochondrial ATP synthase dimers assemble spontaneously into rows upon membrane reconstitution, likely the first step in the formation of mitochondrial cristae.

82. linuma T, Aoki T, Arasaki K, Hirose H, Yamamoto A, Samata R, Hauri HP, Arimitsu N, Tagaya M, Tani K: Role of syntaxin 18 in the organization of endoplasmic reticulum subdomains. J Cell Sci 2009, 122:1680-1690.

83. Cai Y, Goodman JM, Pyc M, Mullen RT, Dyer JM, Chapman KD:

- Arabidopsis SEIPIN proteins modulate triacylglycerol accumulation and influence lipid droplet proliferation. Plant Cell 2015, 27:2616-2636.

First role of SEIPIN in regulation lipid droplet formation in plants.

84. Taurino M, Costantini S, De Domenico S, Stefanelli F, Ruano G, Delgadillo MO, Sanchez-Serrano JJ, Sanmartin M, Santino A, Rojo E: SEIPIN proteins mediate lipid droplet biogenesis to promote pollen transmission and reduce seed dormancy. Plant Physiol 2018, 176:1531-1546.

85. Thazar-Poulot N, Miquel M, Fobis-Loisy I, Gaude T: Peroxisome extensions deliver the Arabidopsis SDP1 lipase to oil bodies. Proc Natl Acad Sci U S A 2015, 112:4158-4163.

86. Hunte C, Richers S: Lipids and membrane protein structures.

87. Maslennikov I, Choe S: Advances in NMR structures of integral membrane proteins. Curr Opin Struct Biol 2013, 23:555-562.

88. Oxenoid $\mathrm{K}$, Chou JJ: The present and future of solution NMR in investigating the structure and dynamics of channels and transporters. Curr Opin Struct Biol 2013, 23:547-554.

89. Nicolas WJ, Grison MS, Trepout S, Gaston A, Fouche M

- Cordelieres FP, Oparka K, Tilsner J, Brocard L, Bayer EM: Architecture and permeability of post-cytokinesis plasmodesmata lacking cytoplasmic sleeves. Nat Plants 2017 3:17082.

Using electron tomography the authors shows that within plasmodesmata ER-PM contact sites undergo substantial remodelling events during cell differentiation to regulate cell-cell communication.

90. Hosy E, Martiniere A, Choquet D, Maurel C, Luu DT: Super-

- resolved and dynamic imaging of membrane proteins in plant cells reveal contrasting kinetic profiles and multiple confinement mechanisms. Mol Plant 2015, 8:339-342. Curr Opin Struct Biol 2008, 18:406-411. 
10 Cell biology

Proof of concept for the use of spt-PALM in plant PM proteins.

91. Deleu M, Crowet JM, Nasir MN, Lins L: Complementary biophysical tools to investigate lipid specificity in the interaction between bioactive molecules and the plasma membrane: a review. Biochim Biophys Acta 2014, 1838:3171-3190.

92. Frisz JF, Klitzing HA, Lou K, Hutcheon ID, Weber PK, Zimmerberg J, Kraft ML: Sphingolipid domains in the plasma membranes of fibroblasts are not enriched with cholesterol. $J$ Biol Chem 2013, 288:16855-16861.

93. Frisz JF, Lou K, Klitzing HA, Hanafin WP, Lizunov V, Wilson RL, Carpenter KJ, Kim R, Hutcheon ID, Zimmerberg J et al.: Direct chemical evidence for sphingolipid domains in the plasma membranes of fibroblasts. Proc Natl Acad Sci U S A 2013, 110 E613-E622.

94. Ondrasek G, Rengel Z, Clode PL, Kilburn MR, Guagliardo P, Romic D: Zinc and cadmium mapping by NanoSIMS within the root apex after short-term exposure to metal contamination. Ecotoxicol Environ Saf 2019, 171:571-578.

95. Epand RM, D'Souza K, Berno B, Schlame M: Membrane curvature modulation of protein activity determined by NMR. Biochim Biophys Acta 2015, 1848:220-228.

96. Molugu TR, Lee S, Brown MF: Concepts and methods of solidstate NMR spectroscopy applied to biomembranes. Chem Rev 2017, 117:12087-12132.

97. Loquet A, El Mammeri N, Stanek J, Berbon M, Bardiaux B,

- Pintacuda G, Habenstein B: 3D structure determination of amyloid fibrils using solid-state NMR spectroscopy. Methods 2018, 138-139:26-38.

Structural studies of molecular assemblies such as amyloids are one of the major application of solid-state NMR. This review concisely describes state-of-the-art ssNMR methods to investigate structures of protein assemblies. The explained methods can generally be applied to elucidate structures of molecular assemblies.

98. Habenstein B, Loquet A: Solid-state NMR: an emerging technique in structural biology of self-assemblies. Biophys Chem 2016, 210:14-26.

99. Weingarth M, Baldus M: Solid-state NMR-based approaches for supramolecular structure elucidation. Acc Chem Res 2013, 46:2037-2046.

100. Mandala VS, Williams JK, Hong M: Structure and dynamics of -. membrane proteins from solid-state NMR. Annu Rev Biophys 2018, 47:201-222.

The authors review ssNMR studies that ingeniously combine different ssNMR approaches to understand membrane protein structure and functional mechanisms. Protein structures, as well as protein-lipid interactions, are discussed from an ssNMR point of view.

101. Opella SJ, Marassi FM: Applications of NMR to membrane proteins. Arch Biochem Biophys 2017, 628:92-101.

102. Ladizhansky V: Applications of solid-state NMR to membrane proteins. Biochim Biophys Acta Proteins Proteom 2017, 1865:1577-1586.

103. Castellani F, van Rossum B, Diehl A, Schubert M, Rehbein K, Oschkinat $\mathrm{H}$ : Structure of a protein determined by solid-state magic-angle-spinning NMR spectroscopy. Nature 2002 , 420:98-102.

104. Wasmer C, Soragni A, Sabate R, Lange A, Riek R, Meier BH: Infectious and noninfectious amyloids of the HET-s(218-289) prion have different NMR spectra. Angew Chem Int Ed Engl 2008, 47:5839-5841.

105. Habenstein B, Loquet A, Hwang S, Giller K, Vasa SK, Becker S, Habeck M, Lange A: Hybrid structure of the type 1 pilus of uropathogenic Escherichia coli. Angew Chem Int Ed Engl 2015 54:11691-11695.

106. Loquet A, Sgourakis NG, Gupta R, Giller K, Riedel D, Goosmann C Griesinger C, Kolbe M, Baker D, Becker S et al:: Atomic model of the type III secretion system needle. Nature 2012, 486:276-279.

107. Retel JS, Nieuwkoop AJ, Hiller M, Higman VA, Barbet-Massin E,

- Stanek J, Andreas LB, Franks WT, van Rossum BJ, Vinothkumar KR et al.: Structure of outer membrane protein $\mathbf{G}$ in lipid bilayers. Nat Commun 2017, 8:2073.

Recent MAS ssNMR approaches have been used to determine the structure of an integral membrane protein. This study is a well-timed example of the potential of MAS ssNMR in structural investigations on membrane proteins.

108. Huster D: Solid-state NMR spectroscopy to study protein-lipid interactions. Biochim Biophys Acta 2014, 1841:1146-1160.

109. Brown LS, Ladizhansky V: Membrane proteins in their native habitat as seen by solid-state NMR spectroscopy. Protein Sci 2015, 24:1333-1346.

110. Elkins MR, Hong M: Elucidating ligand-bound structures of membrane proteins using solid-state NMR spectroscopy. Curr Opin Struct Biol 2019, 57:103-109.

111. Long SB, Tao X, Campbell EB, MacKinnon R: Atomic structure of a voltage-dependent $\mathrm{K}+$ channel in a lipid membrane-like environment. Nature 2007, 450:376-382.

112. Wang J, Pielak RM, McClintock MA, Chou JJ: Solution structure and functional analysis of the influenza $B$ proton channel. Nat Struct Mol Biol 2009, 16:1267-1271. 